Vol. 1 No. 2 Desember 2021, e-ISSN : 2807-8667| p-ISSN : 2807-8837

\title{
UPAYA MENINGKATKAN KETERAMPILAN PROSES SAINS PADA MATERI SISTEM EKSKRESI DENGAN MENGGUNAKAN MODEL PEMBELAJARAN STAD (STUDENT TEAMS ACHIEVEMENT DIVISION) PADA SISWA KELAS XI IPA 3 SMA NEGERI 1 CISAAT
}

\author{
AI JAMILAH \\ SMA Negeri 1 Cisaat \\ e-mail: aijamilah1979@gmail.com
}

\begin{abstract}
ABSTRAK
Penelitian Tindakan Kelas (PTK) ini, bertujuan untuk mendapatkan deskripsi nyata hasil keterampilan proses sains siswa kelas XI pada materi sistem ekskresi dengan menggunakan model pembelajaran STAD, mengetahui proses keterampilan proses sains siswa kelas XI IPA 3 dalam materi sistem ekskresi sebelum dan sesudah menggunakan model pembelajaran STAD dan mengetahui seberapa besar peningkatan hasil keterampilan proses sains siswa kelas XI IPA 3 pada materi sistem ekskresi dengan menggunakan model STAD. Subjek penelitian adalah siswa kelas XI IPA 3 SMA Negeri 1 Cisaat tahun pelajaran 2018/2019 yang berjumlah 40 siswa, 29 perempuan dan 11 laki-laki. Penelitian dilaksanakan dalam dua siklus, menggunakan metode deskriptif analitik model untuk mengetahui proses pembelajaran STAD (Student Teams Achievement Division), peningkatan keterampilan proses sains terhadap hasil belajar peserta didik. Hasil penelitian menunjukkan bahwa proses pembelajaran menggunakan model pembelajaran kooperatif STAD (Student Teams Achievement Division) dapat meningkatkan nilai tes peserta didik, dapat meningkatkan jumlah peserta didik yang mencapai KKM. Prosentase aktifitas siswa tertinggi pada siklus 1 sebesar $20 \%$ sedangkan pada siklus 2 ada peningkatan sebesar 30\%, sebagian besar masih harus ditingkatkan lagi aktivitas nya. Nilai hasil tes dari siklus pertama ke siklus kedua terdapat peningkatan. Pada siklus pertama diperoleh hasil tes tertinggi 72,75 sedangkan pada siklus kedua diperoleh nilai 87 . Nilai tes mengalami kenaikan dari siklus pertama ke siklus ke dua, baik rata-rata nilai maupun jumlah peserta didik yang mencapai KKM. Pada siklus pertama rata-rata 77,5\% peserta didik yang nilai hasil tesnya sudah mencapai KKM, berarti 22,5\% belum mencapai KKM. Pada siklus kedua peserta didik yang nilai hasil tes sudah mencapai KKM adalah $87,5 \%$, dan $12,5 \%$ belum mencapai KKM. Berdasarkan penelitian tersebut disimpulkan bahwa penerapan model pembelajaran STAD (Student Teams Achievement Division) pada mata pelajaran Biologi dapat meningkatkan keterampilan proses sains aktivitas dan hasil tes peserta didik kelas XI IPA 3 SMA Negeri 1 Cisaat semester genap tahun 2019.
\end{abstract}

Kata kunci: model pembelajaran STAD (Student Teams Achievement Division), keterampilan proses sains, aktifitas, hasil tes.

\footnotetext{
ABSTRACT

This Classroom Action Research (CAR) aims to get a real description of the results of the science process skills of class XI students on the excretory system material using the STAD learning model, knowing the process of science process skills of class XI IPA 3 students in the excretory system material before and after using the STAD learning model. and find out how much the increase in the results of the science process skills of class XI IPA 3 students on the excretory system material using the STAD model. The research subjects were students of class XI IPA 3 of SMA Negeri 1 Cisaat in the 2018/2019 school year, totaling 40 students, 29 girls and 11 boys. The research was carried out in two cycles, using a descriptive analytical model to determine the STAD (Student Teams Achievement Division) learning process, increasing science process skills on student learning outcomes. The results of the study indicate that the learning process using the STAD (Student Teams Achievement Division) cooperative learning model can increase students' test scores, can increase the number of students who reach the KKM. The highest percentage of student activity in cycle 1 was $20 \%$ while in cycle 2 there was
} 
an increase of $30 \%$, most of which still had to be increased again. The value of the test results from the first cycle to the second cycle there was an increase. In the first cycle, the highest test result was 72.75, while in the second cycle, the score was 87 . The test scores increased from the first cycle to the second cycle, both the average score and the number of students who reached the KKM. In the first cycle, an average of $77.5 \%$ of students whose test scores have reached the KKM, means that $22.5 \%$ have not reached the KKM. In the second cycle, students whose test scores have reached the KKM are $87.5 \%$, and $12.5 \%$ have not reached the KKM. Based on this research, it was concluded that the application of the STAD (Student Teams Achievement Division) learning model in Biology subjects could improve the activity science process skills and test results of students in class XI IPA 3 SMA Negeri 1 Cisaat even semester of 2019.

Keywords: STAD (Student Teams Achievement Division) learning model, science process skills, activities, test results.

\section{PENDAHULUAN}

Perkembangan zaman yang semakin maju saat ini menuntut terciptanya manusia yang berkualitas untuk bisa mengimbanginya, sehingga hal ini menjadi alasan betapa pentingnya pendidikan bagi manusia. Melalui pendidikan yang dilaksanakan tersebut, perkembangan intelektual seseorang pun bisa meningkat sejalan dengan pengetahuan yang didapatkannya.

Pendidikan menurut Sa'ud (2006: 6) merupakan upaya yang dapat mempercepat pengembangan potensi manusia untuk mampu mengemban tugas yang dibebankan padanya, karena hanya manusia yang dapat dididik dan mendidik. Sedangkan menurut UU Republik Indonesia No. 20 Tahun 2003 tentang Sistem Pendidikan Nasional menyatakan bahwa:

Pendidikan adalah usaha sadar dan terencana untuk mewujudkan suasana belajar dan proses pembelajaran agar peserta didik secara aktif mengembangkan potensi dirinya untuk memiliki kekuatan spiritual keagamaan, pengendalian diri, kepribadian, kecerdasan, akhlak mulia, serta keterampilan yang diperlukan dirinya, masyarakat, bangsa, dan negara.

Pelaksanaan pendidikan tersebut bertujuan untuk berkembangnya potensi peserta didik agar menjadi manusia yang beriman dan bertakwa kepada Tuhan Yang Maha Esa, berakhlak mulia, sehat, berilmu, cakap, kreatif, mandiri, dan menjadi warga negara yang demokratis serta bertanggung jawab. Selain itu juga berfungsi memberikan arah pada semua kegiatan pendidikan dalam satuan-satuan pendidikan yang ada. Tujuan pendidikan nasional itu, merupakan tujuan umum yang hendak dicapai oleh semua satuan pendidikan nasional.

Menurut Sudjana (2002: 1-2) ada tiga variabel utama yang saling berkaitan dalam strategi pelaksanaan pendidikan di sekolah. Ketiga variabel tersebut adalah kurikulum, guru, dan pengajaran atau proses belajar mengajar. Kurikulum dipandang/diartikan sebagai program belajar bagi siswa (plan for learning) yang disusun secara sistematik, dan diberikan oleh lembaga pendidikan tertentu untuk mencapai tujuan pendidikan. Atas dasar itulah ada pandangan yang menyatakan bahwa kurikulum tidak lain adalah hasil belajar yang diniati/diharapkan atau intended learning out come. Guru menempati kedudukan sentral sebab peranannya sangat menentukan. Ia harus mampu menterjemahkan dan menjabarkan nilai-nilai yang terdapat dalam kurikulum, kemudian mentransformasikan nilai-nilai tersebut kepada siswa melalui proses pengajaran di sekolah.

Pendidikan biologi merupakan bagian dari pendidikan sains dan sebagai salah satu mata pelajaran di sekolah yang diharapkan dapat mencapai tujuan pendidikan nasional yang ada. Biologi merupakan wahana untuk meningkatkan ilmu pengetahuan, keterampilan sikap serta bertanggung jawab kepada lingkungan. Biologi berkaitan dengan cara mencari tahu dan memahami alam dan makhluk hidup secara sistematis sehingga pembelajaran biologi bukan hanya penguasaan kumpulan-kumpulan fakta tetapi juga proses penemuan. Selain itu Biologi merupakan salah satu pendidikan dan langkah awal bagi seorang anak mengenal dan memahami konsep-konsep tentang alam untuk membangun keahlian dan kemampuan berpikirnya agar dapat berperan aktif menerapkan ilmunya dalam dunia teknologi. 
Sistem ekskresi merupakan bagian dari materi biologi. Di dalam Kurikulum Tingkat Satuan Pendidikan (KTSP) tahun 2013, sistem ekskresi adalah salah satu materi pokok yang diajarkan di kelas XI semester II SMA yang memuat tentang sistem ekskresi pada hewan, alatalat ekskresi, mekanisme ekskresi pada manusia, dan kelainan atau penyakit yang terjadi dalam sistem ekskresi. Untuk menguasai materi tersebut diperlukan strategi dan model pembelajaran tertentu supaya siswa dapat memahami materi pelajaran yang dipelajari secara maksimal sehingga dapat meningkatkan hasil belajar terutama dalam Keterampilan Proses Sains siswa.

Dewasa ini, berbagai macam komentar telah diberikan berkaitan dengan rendahnya hasil belajar siswa terutama dalam Keterampilan Proses Sains siswa mata pelajaran biologi. Dengan adanya kenyataan ini perlu ditingkatkan mutu pendidikan termasuk pengajaran Biologi.

Selama ini guru telah melakukan berbagai cara dengan menggunakan metode yang bervariasi untuk membantu siswa agar lebih aktif dan dapat menguasai materi pelajaran sehingga hasil belajarnya lebih baik, tapi kenyataannya hasil belajar siswa masih rendah. Berdasarkan pandangan di atas, maka permasalahan yang muncul adalah bagaimana upaya guru untuk meningkatkan hasil belajar siswa dengan menggunakan pendekatan atau model yang tepat, maka perlu dilakukan suatu penelitian untuk menemukan sebuah alternatif dalam upaya meningkatkan kualitas pembelajaran guna meningkatkan hasil belajar siswa. Salah satu alternatifnya yaitu dengan mengembangkan model pembelajaran kooperatif atau cooperative learning yang saat ini sedang banyak diterapkan, sehingga diharapkan dapat meningkatkan motivasi dan aktivitas siswa untuk belajar.

Cooperative learning merupakan salah satu penerapan pendekatan kontruktivisme. Menurut aliran ini, pengetahuan itu dibangun sendiri dalam pikiran siswa yang dapat diperoleh dari pengalaman fisik dan juga dari orang lain melalui transmisi sosial. Selain itu, pengetahuan tidak dapat ditransfer begitu saja dari seorang guru kepada siswa, tetapi siswa sendiri yang harus memaknai apa yang telah diajarkan dengan menyesuaikan terhadap pemahamannya.

Menurut Isjoni (2009: 16), cooperative learning adalah suatu model pembelajaran untuk mewujudkan kegiatan belajar mengajar yang berpusat pada siswa (student oriented), terutama untuk mengatasi permasalahan yang ditemukan guru dalam mengaktifkan siswa, yang tidak dapat bekerja sama dengan orang lain, siswa yang agresif, dan tidak peduli pada yang lain. Model pembelajaran ini telah terbukti dapat digunakan dalam berbagai mata pelajaran dan berbagai usia. Penerapan model cooperative learning sekitar 60 persen belum bisa dilaksanakan sepenuhnya oleh siswa karena masih terbiasa dengan model ceramah. Dengan adanya penerapan model cooperative learning di kelas untuk melatih siswa menerima pendapat orang lain dan berkerja sama dengan teman yang berbeda latar belakangnya, membantu memudahkan menerima materi pelajaran, dan meningkatkan kemampuan berfikir dalam memecahkan masalah seperti yang terjadi di kelas XI IPA3 SMA Negeri 1 Cisaat. Karena dengan adanya komunikasi antara anggota-anggota kelompok dalam menyampaikan pengetahuan serta pengalamannya sehingga siswa dapat menambahkan pengetahuan dan meningkatkan hasil belajar serta hubungan sosial setiap anggota kelompok.

Salah satu model pembelajaran kooperatif adalah tipe STAD, model ini memberi siswa kesempatan untuk bekerja sendiri serta bekerja sama dengan orang lain. Dengan demikian melalui penerapan model STAD ini diharapkan hasil belajar siswa dalam hal keterampilan proses sains dapat meningkat.

\section{METODE PENELITIAN}

Penelitian Tindakan Kelas ini dilaksanakan di kelas XI IPA 3 SMA Negeri 1 Cisaat pada semester genap tahun 2019. Jumlah keseluruhan peserta didik di kelas XI IPA 3 SMA Negeri 1 Cisaat berjumlah 40 siswa, 29 perempuan dan 11 laki-laki. Penelitian Tindakan Kelas ini dirancang untuk dilaksanakan dalam dua siklus yang berkelanjutan dalam satu semester. Setiap siklus dilaksanakan dengan dua kali pertemuan, siklus ke 1 dilaksanakan pada minggu ke 1 bulan Agustus dan siklus 2 dilaksanakan pada minggu ke 2 bulan Agustus 2019. Penelitian tindakan kelas ini menggunakan model dengan 4 (empat) tahapan dasar yang saling terkait dan 
berkesinambungan: (1) perencanaan (planning), (2) tindakan (action), (3) pengamatan (observing), dan (4) refleksi (reflecting). Siklus pertama terdiri dari dua pertemuan, pertemuan pertama membahas organ-organ ekskresi, metoda yang digunakan adalah diskusi kelompok secara STAD, pertemuan kedua membahas mengenai Fungsi organ-organ ekskresi. Adapun tahapan dalam siklus pertama yaitu Perencanaan meliputi membuat silabus membuat rencana pelaksanaan pembelajaran untuk dua kali pertemuan, membuat instrumen pembelajaran, mengelompokan siswa dan mengajak teman sejawat berdiskusi tentang pelaksanaan observasi. Pada kegiatan tindakan yaitu melaksanakan skenario pembelajaran sesuai yang direncanakan, secara berkelompok siswa mendapat tugas, satu persatu kelompok mempresentasikan hasil kerja kelompoknya, guru meberikan hadiah pada tiap kelompok berupa kelompok super, kelompok hebat dan kelompok baik.

Selama proses pembelajaran berlangsung observer mengamati dan mencatat kegiatan berlangsung pada format pengamatan yang telah disediakan. Aspek-aspek yang diamati antara lain meliputi: Aktivitas guru dalam proses pembelajaran, aktivitas siswa, dam kemampuan siswa menguasai materi sistem ekskresi.

Pada kegiatan observer beserta peneliti mengkaji kelemahan dan kelebihan proses pembelajaran yang sudah berlangsung. Hasil dari kegiatan ini menjadi bahan pertimbangan untuk menentukan tindakan pada siklus berikutnya.

Pada siklus ke dua tahapannya sama dengan siklus pertama, tetapi terjadi beberapa perbaikan pada rencana pembelajaran sesuai hasil refleksi pada siklus pertama. Siklus kedua terdiri dari dua pertemuan, pertemuan pertama siswa melakukan praktikum uji urin, pertemuan kedua membahas mengenai kandungan zat yang terdapat pada urin setelah siswa melakukan praktikum.

\section{HASIL DAN PEMBAHASAN}

Penelitian tindakan kelas ini dilakukan pada materi sistem ekskresi, maka sebagai pembanding adalah hasil tes kesatu dan kedua. Rata- rata nilai hasil tes ke 1 adalah 72,75 sedangkan peserta yang mencapai KKM sebanyak 31 orang. Rata- rata nilai hasil ulangan tes ke 2 adalah 87 sedangkan peserta yang mencapai KKM sebanyak 35 orang dari jumlah peserta didik 40 orang.

\section{Hasil}

\section{Hasil Penelitian Siklus 1}

Penelitian tindakan kelas ini memfokuskan pada hasil belajar siswa, melalui pengamatan aktifitas dan kreatifitas peserta didik dalam proses pembelajaran serta nilai hasil tes. Aktifitas dan kreatifitas siswa diamati langsung oleh observer yang dicatat dalam lembar observasi. Sedangkan nilai hasil tes diperoleh setelah dilaksanakan keterampilan proses sains pada pertemuan kedua dalam tiap siklus.

Tabel 1. Hasil pengamatan aktivitas siswa siklus ke- i

\begin{tabular}{|c|c|c|c|c|}
\hline Kelompok & Nama Siswa & $\begin{array}{c}\text { Skor } \\
\text { Perolehan }\end{array}$ & $\begin{array}{l}\text { Skor } \\
\text { Ideal }\end{array}$ & Persentase \\
\hline \multirow{4}{*}{1} & ANISA SRI RAHAYU & \multirow{4}{*}{14} & \multirow{4}{*}{16} & \multirow{4}{*}{87} \\
\hline & BIAS FAJAR KHALIQ & & & \\
\hline & CHELSI ANDESCO & & & \\
\hline & DANIA SARASWATI & & & \\
\hline \multirow{4}{*}{2} & DIKI APRIAN & \multirow{4}{*}{12} & \multirow{4}{*}{16} & \multirow{4}{*}{75} \\
\hline & DION ANUGRAH PRATAMA & & & \\
\hline & INDRI HIDAYANTI & & & \\
\hline & INTAN YUNIA CAHYANI & & & \\
\hline
\end{tabular}


Vol. 1 No. 2 Desember 2021, e-ISSN : 2807-8667| p-ISSN : 2807-8837

\begin{tabular}{|c|c|c|c|c|}
\hline \multirow{5}{*}{3} & & \multirow{5}{*}{14} & & \multirow{5}{*}{87} \\
\hline & IRVAN TANJUNG & & \multirow{4}{*}{16} & \\
\hline & MELI WIDIANINGSIH & & & \\
\hline & MIMIN M & & & \\
\hline & MUH LABIB ZAMAKHSYARI & & & \\
\hline \multirow{4}{*}{4} & $\begin{array}{l}\text { MUHAMMAD ADNAN } \\
\text { ALFARIZI }\end{array}$ & \multirow{4}{*}{12} & \multirow{4}{*}{16} & \multirow{4}{*}{75} \\
\hline & MUHAMMAD RIZAL & & & \\
\hline & MUHAMMAD SIRAJUDIN & & & \\
\hline & NADYA FEBRIYANTI UTAMI & & & \\
\hline \multirow{4}{*}{5} & $\begin{array}{l}\text { NIK NIK HERNIKA } \\
\text { NIKEWATI }\end{array}$ & \multirow{4}{*}{12} & \multirow{4}{*}{16} & \multirow{4}{*}{75} \\
\hline & NINA RUSMAYANI & & & \\
\hline & NINDA NURLATIFAH & & & \\
\hline & NOVITA RAHMAWATI & & & \\
\hline \multirow{4}{*}{6} & NUKE MARLIANI & \multirow{4}{*}{12} & \multirow{4}{*}{16} & \multirow{4}{*}{75} \\
\hline & NURUL FAINI GORO & & & \\
\hline & PETI PAJRIATI & & & \\
\hline & PIPIT PITRIANA & & & \\
\hline \multirow{4}{*}{7} & PUTRI AULIA WITASYA & \multirow{4}{*}{13} & \multirow{4}{*}{16} & \multirow{4}{*}{81} \\
\hline & RINA SRI RAHAYU & & & \\
\hline & RISMA ASHOFI & & & \\
\hline & RIZKI APRIANI & & & \\
\hline \multirow{4}{*}{8} & ROSSYANA IRWANDI & \multirow{4}{*}{12} & \multirow{4}{*}{16} & \multirow{4}{*}{75} \\
\hline & RUDIANSYAH & & & \\
\hline & RUSLAN MAULANA & & & \\
\hline & SATRIA RIZKI ROHMAT & & & \\
\hline \multirow{4}{*}{9} & SITI RAHAYU NURLATIPAH & \multirow{4}{*}{12} & \multirow{4}{*}{16} & \multirow{4}{*}{75} \\
\hline & SITI SARAH NURAENI & & & \\
\hline & SITI SARAH NURDAYANTI & & & \\
\hline & VINA YUNIA MAULIDA & & & \\
\hline \multirow{4}{*}{10} & WINDA APRILIANI & & & \\
\hline & ZULFAH MUSLIMAH & 10 & 16 & 62 \\
\hline & NURDANIA & 10 & 10 & 02 \\
\hline & SOFIE NUR FAUZIAH ARIFIN & & & \\
\hline
\end{tabular}

Kesimpulan mengenai aktivitas siswa pada siklus 1 dapat dilihat sebagai berikut:

Tabel 2. Data aktivitas siswa pada siklus 1

\begin{tabular}{|l|l|l|}
\hline Aktivitas Siswa & Jumlah Siswa & Prosentase \\
\hline Tertinggi & 8 & $20 \%$ \\
\hline Sedang & 28 & $70 \%$ \\
\hline Terendah & 4 & $10 \%$ \\
\hline
\end{tabular}


Vol. 1 No. 2 Desember 2021, e-ISSN : 2807-8667| p-ISSN : 2807-8837

Dari tabel data siswa pada siklus 1, aktivitas siswa tertinggi sebanyak $20 \%$, aktivitas siswa sedang sebanyak $70 \%$ dan aktivitas siswa rendah sebanyak $10 \%$.

Diagram aktivitas siswa pada siklus 1 dapat dilihat pada gambar di bawah ini

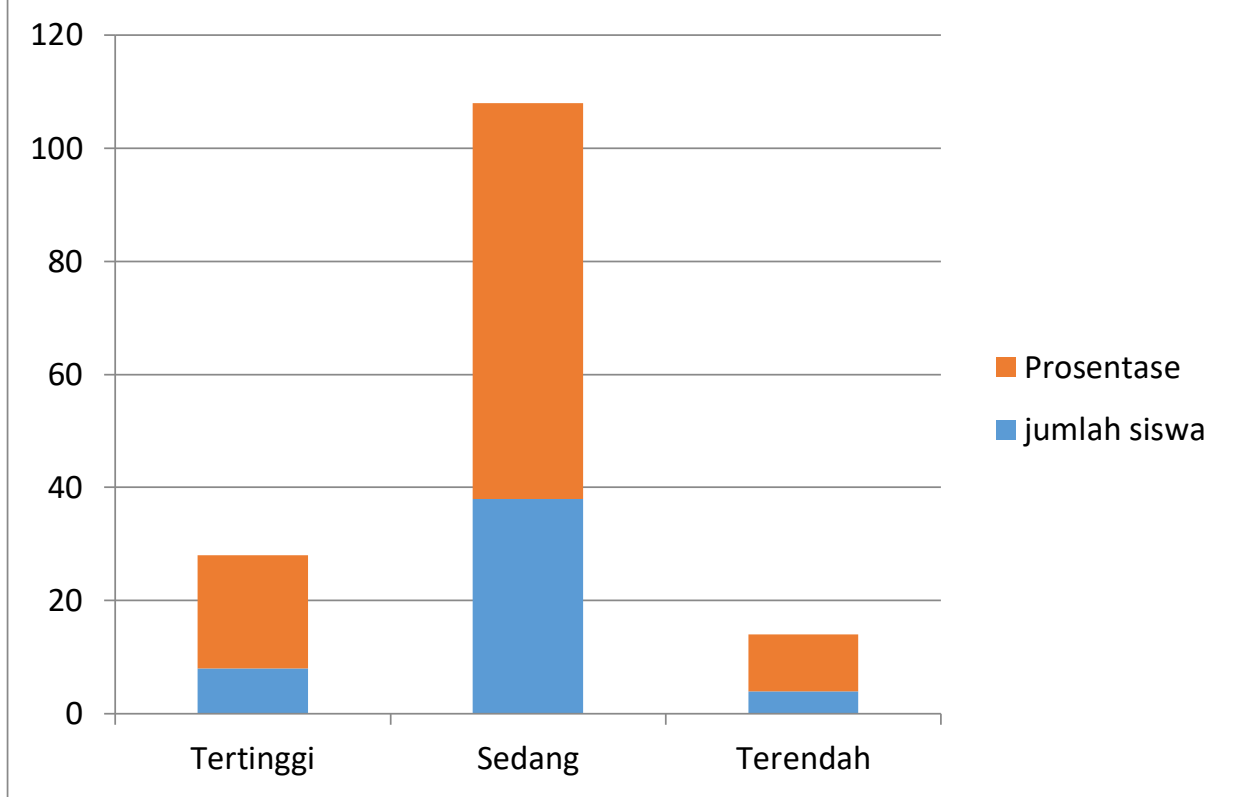

Gambar 1. Hasil aktivitas siswa pada siklus 1

Dari data aktivitas siswa siswa yang aktif hanya 2 kelompok yaitu sebanyak 8 orang dan yang lainnya masih kurang aktif, oleh karena itu peran guru harus lebih aktif dalam menerapkan model pembelajaran ini.

Tabel 3. Hasil Penilaian Siswa Pada Siklus I

\begin{tabular}{|c|c|c|c|c|c|c|c|c|c|c|}
\hline \multirow{3}{*}{ NO } & \multirow{3}{*}{ NAMA SISWA } & \multicolumn{7}{|c|}{ SKOR SOAL } & \multirow{3}{*}{$\begin{array}{c}\text { NIL } \\
\text { AI }\end{array}$} & \multirow{3}{*}{$\begin{array}{c}\text { KETUNTA } \\
\text { SAN }\end{array}$} \\
\hline & & \multicolumn{6}{|c|}{1} & \multirow{2}{*}{2} & & \\
\hline & & A & B & $\mathrm{C}$ & $\mathrm{D}$ & $\mathrm{E}$ & $\mathrm{F}$ & & & \\
\hline & & 1 & 1 & 1 & 1 & 1 & 1 & 2 & & \\
\hline 1 & ANISA SRI RAHAYU & 0 & 0 & 0 & 0 & 0 & 0 & 0 & 80 & TUNTAS \\
\hline & & 1 & 1 & & 1 & 1 & 1 & 3 & & \\
\hline 2 & BIAS FAJAR KHALIQ & 0 & 0 & 0 & 0 & 0 & 0 & 0 & 80 & TUNTAS \\
\hline & & 1 & 1 & 1 & 1 & 1 & 1 & 1 & & \\
\hline 3 & CHELSI ANDESCO & 0 & 0 & 0 & 0 & 0 & 0 & 0 & 70 & TUNTAS \\
\hline & & 1 & 1 & 1 & 1 & 1 & 1 & 2 & & \\
\hline 4 & DANIA SARASWATI & 0 & 0 & 0 & 0 & 0 & 0 & 0 & 80 & TUNTAS \\
\hline & & 1 & 1 & 1 & & 1 & 1 & 1 & & TIDAK \\
\hline 5 & DIKI APRIAN & 0 & 0 & 0 & 0 & 0 & 0 & 0 & 60 & TUNTAS \\
\hline & DION ANUGRAH & 1 & 1 & 1 & & 1 & & 4 & & \\
\hline 6 & PRATAMA & 0 & 0 & 0 & 0 & 0 & 0 & 0 & 80 & TUNTAS \\
\hline & & 1 & & & 1 & 1 & 1 & 4 & & \\
\hline 7 & INDRI HIDAYANTI & 0 & 0 & 0 & 0 & 0 & 0 & 0 & 80 & TUNTAS \\
\hline & INTAN YUNIA & 1 & & 1 & & 1 & 1 & 3 & & \\
\hline 8 & CAHYANI & 0 & 0 & 0 & 0 & 0 & 0 & 0 & 70 & TUNTAS \\
\hline & & & 1 & & 1 & 1 & & 4 & & \\
\hline 9 & IRVAN TANJUNG & 0 & 0 & 0 & 0 & 0 & 0 & 0 & 70 & TUNTAS \\
\hline & & 1 & 1 & 1 & & 1 & 1 & 2 & & \\
\hline 10 & MELI WIDIANINGSIH & 0 & 0 & 0 & 0 & 0 & 0 & 0 & 70 & TUNTAS \\
\hline
\end{tabular}


Vol. 1 No. 2 Desember 2021, e-ISSN : 2807-8667| p-ISSN : 2807-8837

\begin{tabular}{|c|c|c|c|c|c|c|c|c|c|c|}
\hline 11 & MIMIN M & $\begin{array}{l}1 \\
0\end{array}$ & $\begin{array}{l}1 \\
0\end{array}$ & $\begin{array}{l}1 \\
0\end{array}$ & $\begin{array}{l}1 \\
0\end{array}$ & $\begin{array}{l}1 \\
0\end{array}$ & 0 & $\begin{array}{l}1 \\
0\end{array}$ & 60 & $\begin{array}{l}\text { TIDAK } \\
\text { TUNTAS }\end{array}$ \\
\hline 12 & $\begin{array}{l}\text { MUH LABIB } \\
\text { ZAMAKHSYARI }\end{array}$ & $\begin{array}{l}1 \\
0\end{array}$ & $\begin{array}{l}1 \\
0\end{array}$ & $\begin{array}{l}1 \\
0\end{array}$ & $\begin{array}{l}1 \\
0\end{array}$ & $\begin{array}{l}1 \\
0\end{array}$ & $\begin{array}{l}1 \\
0\end{array}$ & $\begin{array}{l}2 \\
0\end{array}$ & 80 & TUNTAS \\
\hline 13 & $\begin{array}{l}\text { MUHAMMAD ADNAN } \\
\text { ALFARIZI }\end{array}$ & $\begin{array}{l}1 \\
0\end{array}$ & 0 & $\begin{array}{l}1 \\
0\end{array}$ & $\begin{array}{l}1 \\
0\end{array}$ & 0 & $\begin{array}{l}1 \\
0\end{array}$ & $\begin{array}{l}4 \\
0\end{array}$ & 80 & TUNTAS \\
\hline 14 & MUHAMMAD RIZAL & $\begin{array}{l}1 \\
0\end{array}$ & $\begin{array}{l}1 \\
0\end{array}$ & $\begin{array}{l}1 \\
0\end{array}$ & 0 & $\begin{array}{l}1 \\
0\end{array}$ & $\begin{array}{l}1 \\
0\end{array}$ & $\begin{array}{l}3 \\
0\end{array}$ & 80 & TUNTAS \\
\hline 15 & $\begin{array}{l}\text { MUHAMMAD } \\
\text { SIRAJUDIN }\end{array}$ & $\begin{array}{l}1 \\
0\end{array}$ & $\begin{array}{l}1 \\
0\end{array}$ & $\begin{array}{l}1 \\
0\end{array}$ & $\begin{array}{l}1 \\
0\end{array}$ & $\begin{array}{l}1 \\
0\end{array}$ & $\begin{array}{l}1 \\
0\end{array}$ & $\begin{array}{l}2 \\
0\end{array}$ & 80 & TUNTAS \\
\hline 16 & $\begin{array}{l}\text { NADYA FEBRIYANTI } \\
\text { UTAMI }\end{array}$ & $\begin{array}{l}1 \\
0\end{array}$ & $\begin{array}{l}1 \\
0\end{array}$ & $\begin{array}{l}1 \\
0\end{array}$ & $\begin{array}{l}1 \\
0\end{array}$ & $\begin{array}{l}1 \\
0\end{array}$ & $\begin{array}{l}1 \\
0\end{array}$ & $\begin{array}{l}2 \\
0\end{array}$ & 80 & TUNTAS \\
\hline 17 & $\begin{array}{l}\text { NIK NIK HERNIKA } \\
\text { NIKEWATI }\end{array}$ & $\begin{array}{l}1 \\
0\end{array}$ & $\begin{array}{l}1 \\
0\end{array}$ & $\begin{array}{l}1 \\
0\end{array}$ & $\begin{array}{l}1 \\
0\end{array}$ & $\begin{array}{l}1 \\
0\end{array}$ & $\begin{array}{l}1 \\
0 \\
\end{array}$ & $\begin{array}{l}1 \\
0\end{array}$ & 70 & TUNTAS \\
\hline 18 & NINA RUSMAYANI & $\begin{array}{l}1 \\
0\end{array}$ & $\begin{array}{l}1 \\
0\end{array}$ & $\begin{array}{l}1 \\
0\end{array}$ & $\begin{array}{l}1 \\
0\end{array}$ & $\begin{array}{l}1 \\
0\end{array}$ & 0 & $\begin{array}{l}2 \\
0\end{array}$ & 70 & TUNTAS \\
\hline 19 & NINDA NURLATIFAH & $\begin{array}{l}1 \\
0\end{array}$ & 0 & 0 & $\begin{array}{l}1 \\
0\end{array}$ & $\begin{array}{l}1 \\
0\end{array}$ & $\begin{array}{l}1 \\
0 \\
\end{array}$ & $\begin{array}{l}4 \\
0 \\
\end{array}$ & 80 & TUNTAS \\
\hline 20 & NOVITA RAHMAWATI & 0 & $\begin{array}{l}1 \\
0\end{array}$ & $\begin{array}{l}1 \\
0\end{array}$ & $\begin{array}{l}1 \\
0\end{array}$ & $\begin{array}{l}1 \\
0\end{array}$ & $\begin{array}{l}1 \\
0 \\
\end{array}$ & $\begin{array}{l}3 \\
0\end{array}$ & 80 & TUNTAS \\
\hline 21 & NUKE MARLIANI & $\begin{array}{l}1 \\
0\end{array}$ & $\begin{array}{l}1 \\
0\end{array}$ & $\begin{array}{l}1 \\
0\end{array}$ & $\begin{array}{l}1 \\
0\end{array}$ & 0 & 0 & $\begin{array}{l}4 \\
0 \\
\end{array}$ & 80 & TUNTAS \\
\hline 22 & NURUL FAINI GORO & 0 & $\begin{array}{l}1 \\
0\end{array}$ & $\begin{array}{l}1 \\
0\end{array}$ & $\begin{array}{l}1 \\
0\end{array}$ & 0 & $\begin{array}{l}1 \\
0 \\
\end{array}$ & $\begin{array}{l}4 \\
0 \\
\end{array}$ & 80 & TUNTAS \\
\hline 23 & PETI PAJRIATI & $\begin{array}{l}1 \\
0\end{array}$ & $\begin{array}{l}1 \\
0\end{array}$ & 0 & $\begin{array}{l}1 \\
0\end{array}$ & $\begin{array}{l}1 \\
0\end{array}$ & $\begin{array}{l}1 \\
0\end{array}$ & 0 & 50 & $\begin{array}{l}\text { TIDAK } \\
\text { TUNTAS }\end{array}$ \\
\hline 24 & PIPIT PITRIANA & $\begin{array}{l}1 \\
0\end{array}$ & $\begin{array}{l}1 \\
0\end{array}$ & 0 & $\begin{array}{l}1 \\
0\end{array}$ & $\begin{array}{l}1 \\
0\end{array}$ & $\begin{array}{l}1 \\
0 \\
\end{array}$ & $\begin{array}{l}2 \\
0 \\
\end{array}$ & 70 & TUNTAS \\
\hline 25 & $\begin{array}{l}\text { PUTRI AULIA } \\
\text { WITASYA }\end{array}$ & $\begin{array}{l}1 \\
0\end{array}$ & 0 & $\begin{array}{l}1 \\
0\end{array}$ & $\begin{array}{l}1 \\
0\end{array}$ & $\begin{array}{l}1 \\
0\end{array}$ & 0 & $\begin{array}{l}4 \\
0\end{array}$ & 80 & TUNTAS \\
\hline 26 & RINA SRI RAHAYU & $\begin{array}{l}1 \\
0\end{array}$ & $\begin{array}{l}1 \\
0\end{array}$ & $\begin{array}{l}1 \\
0\end{array}$ & 0 & $\begin{array}{l}1 \\
0\end{array}$ & 0 & $\begin{array}{l}4 \\
0\end{array}$ & 80 & TUNTAS \\
\hline 27 & RISMA ASHOFI & 0 & $\begin{array}{l}1 \\
0\end{array}$ & 0 & $\begin{array}{l}1 \\
0\end{array}$ & 0 & $\begin{array}{l}1 \\
0 \\
\end{array}$ & $\begin{array}{l}4 \\
0\end{array}$ & 70 & TUNTAS \\
\hline 28 & RIZKI APRIANI & $\begin{array}{l}1 \\
0\end{array}$ & $\begin{array}{l}1 \\
0\end{array}$ & $\begin{array}{l}1 \\
0\end{array}$ & 0 & $\begin{array}{l}1 \\
0\end{array}$ & 0 & $\begin{array}{l}4 \\
0\end{array}$ & 80 & TUNTAS \\
\hline 29 & ROSSYANA IRWANDI & 0 & $\begin{array}{l}1 \\
0\end{array}$ & $\begin{array}{l}1 \\
0\end{array}$ & $\begin{array}{l}1 \\
0\end{array}$ & $\begin{array}{l}1 \\
0\end{array}$ & $\begin{array}{l}1 \\
0 \\
\end{array}$ & 0 & 50 & $\begin{array}{l}\text { TIDAK } \\
\text { TUNTAS }\end{array}$ \\
\hline 30 & RUDIANSYAH & $\begin{array}{l}1 \\
0\end{array}$ & $\begin{array}{l}1 \\
0\end{array}$ & $\begin{array}{l}1 \\
0\end{array}$ & 0 & $\begin{array}{l}1 \\
0\end{array}$ & $\begin{array}{l}1 \\
0\end{array}$ & $\begin{array}{l}4 \\
0\end{array}$ & 90 & TUNTAS \\
\hline 31 & RUSLAN MAULANA & $\begin{array}{l}1 \\
0\end{array}$ & 0 & $\begin{array}{l}1 \\
0\end{array}$ & 0 & $\begin{array}{l}1 \\
0\end{array}$ & $\begin{array}{l}1 \\
0 \\
\end{array}$ & $\begin{array}{l}2 \\
0 \\
\end{array}$ & 60 & $\begin{array}{l}\text { TIDAK } \\
\text { TUNTAS }\end{array}$ \\
\hline 32 & $\begin{array}{l}\text { SATRIA RIZKI } \\
\text { ROHMAT }\end{array}$ & $\begin{array}{l}1 \\
0\end{array}$ & $\begin{array}{l}1 \\
0\end{array}$ & $\begin{array}{l}1 \\
0\end{array}$ & $\begin{array}{l}1 \\
0\end{array}$ & $\begin{array}{l}1 \\
0\end{array}$ & $\begin{array}{l}1 \\
0\end{array}$ & 0 & 60 & $\begin{array}{l}\text { TIDAK } \\
\text { TUNTAS }\end{array}$ \\
\hline 33 & $\begin{array}{l}\text { SITI RAHAYU } \\
\text { NURLATIPAH }\end{array}$ & 0 & $\begin{array}{l}1 \\
0\end{array}$ & 0 & $\begin{array}{l}1 \\
0\end{array}$ & $\begin{array}{l}1 \\
0\end{array}$ & $\begin{array}{l}1 \\
0 \\
\end{array}$ & $\begin{array}{l}4 \\
0 \\
\end{array}$ & 80 & TUNTAS \\
\hline 34 & SITI SARAH NURAENI & $\begin{array}{l}1 \\
0\end{array}$ & $\begin{array}{l}1 \\
0\end{array}$ & $\begin{array}{l}1 \\
0\end{array}$ & 0 & $\begin{array}{l}1 \\
0\end{array}$ & 0 & $\begin{array}{l}4 \\
0 \\
\end{array}$ & 80 & TUNTAS \\
\hline 35 & $\begin{array}{l}\text { SITI SARAH } \\
\text { NURDAYANTI }\end{array}$ & $\begin{array}{l}1 \\
0\end{array}$ & $\begin{array}{l}1 \\
0\end{array}$ & 0 & $\begin{array}{l}1 \\
0\end{array}$ & $\begin{array}{l}1 \\
0\end{array}$ & $\begin{array}{l}1 \\
0\end{array}$ & $\begin{array}{l}1 \\
0\end{array}$ & 60 & $\begin{array}{l}\text { TIDAK } \\
\text { TUNTAS }\end{array}$ \\
\hline
\end{tabular}


Vol. 1 No. 2 Desember 2021, e-ISSN : 2807-8667| p-ISSN : 2807-8837

\begin{tabular}{|l|l|l|l|l|l|l|l|l|l|l|} 
& VINA YUNIA & & 1 & 1 & & 1 & 1 & 3 & & \\
36 & MAULIDA & 0 & 0 & 0 & 0 & 0 & 0 & 0 & 70 & TUNTAS \\
\hline \multirow{3}{*}{37} & WINDA APRILIANI & 1 & 1 & 1 & 1 & 1 & & 2 & & \\
\hline \multirow{3}{*}{38} & ZULFAH MUSLIMAH & 0 & 0 & 0 & 0 & 0 & 0 & 0 & 70 & TUNTAS \\
\hline \multirow{3}{*}{39} & NURDANIA & 1 & 1 & & 1 & & 1 & 4 & & \\
\hline \multirow{3}{*}{40} & SOFIE NUR FAUZIAH & 0 & 0 & 0 & 0 & 0 & 0 & 0 & 80 & TUNTAS \\
\hline
\end{tabular}

Untuk mengetahui besaran nilai hasil tes siswa, maka pada akhir siklus 1 dilakukan tes dan dapat dilihat pada tabel berikut:

Tabel 4 Daftar nilai hasil belajar siswa pada siklus 1

\begin{tabular}{|l|l|l|l|}
\hline Rata-rata & Nilai tertinggi & Nilai terendah & Ketuntasan (\%) \\
\hline 72,75 & 80 & 50 & 77,5 \\
\hline
\end{tabular}

Dari tabel daftar nilai hasil belajar siswa pada siklus 1 ketuntasan siswa sebesar $77,5 \%$.

Nilai hasil pada siklus 1 dapat di lihat pada gambar di bawah ini

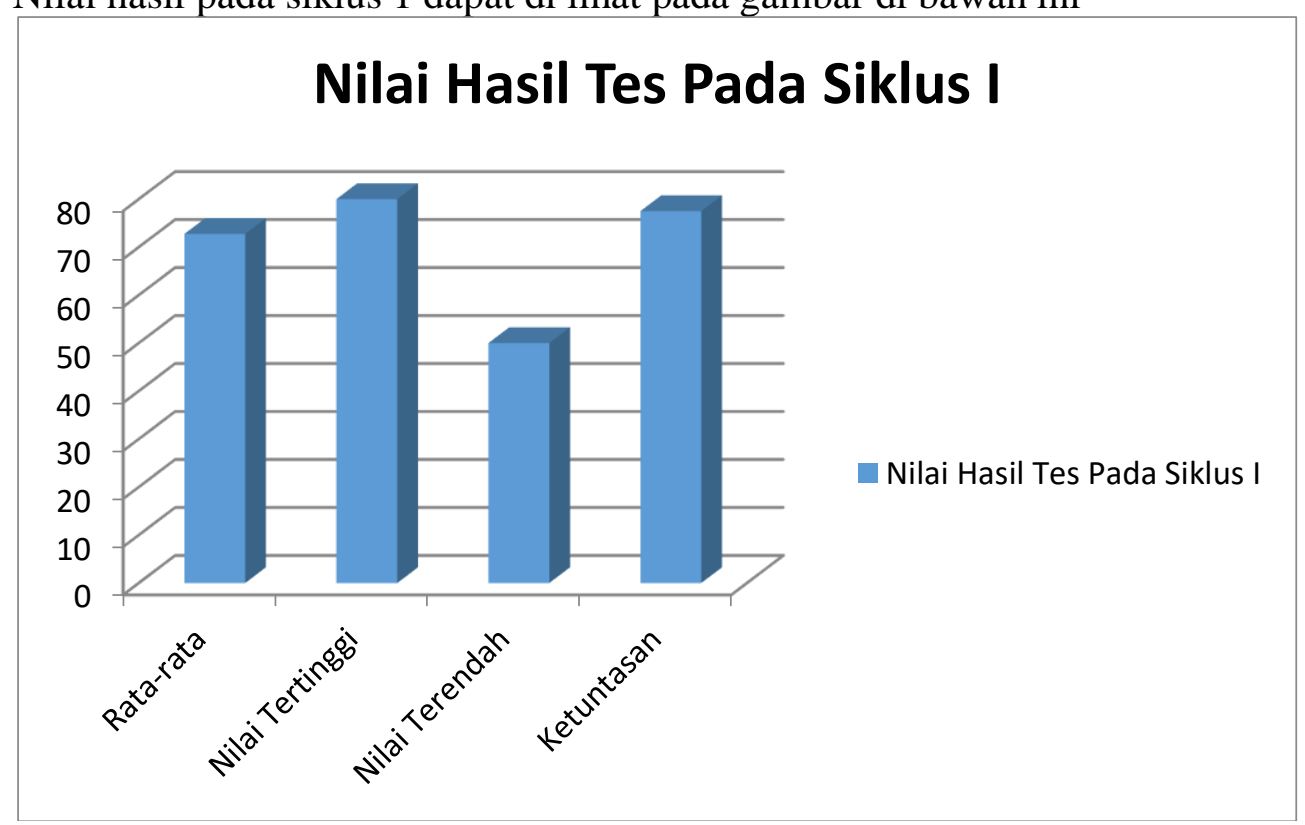

Gambar 2. Gambar hasil tes pada siklus 1

Berdasarkan hasil ulangan harian, nilai rata-rata kelas 72,75, siswa sudah mencapai KKM sebanyak 31 orang sedangkan 11 yang memperoleh nilai di bawah KKM. Dengan demikian persentase peserta didik yang nilai tes nya mencapai KKM hanya 77,50 \%, sisanya belum mencapai KKM.

Sebagai tindak lanjut bagi siswa yang mendapat nilai dibawah KKM dilakukan perbaikan yang pelaksanaannya di luar jam pelajaran sedangkan bagi siswa yang sudah mencapai KKM diberi soal pengayaan yang dikerjakan di rumah.

Berdasarkan catatan dari observer maupun hasil ulangan siswa, proses pembelajaran masih belum sesuai yang diharapkan karena masih banyak siswa yang nilai ulangannya belum tuntas atau di bawah KKM. Selain itu aktivitas siswa pun masih tergolong rendah, yaitu aktivitas siswa paling rendah mencapai $62 \%$ dan tertinggi $87 \%$. Beberapa kekurangan pada siklus pertama : (1) masih banyak peserta didik yang kurang aktif dalam didikusi kelompok 
maupun dalam bertanya dan menanggapi, (2) masih ada kelompok yang salah dalam menjawab pertanyaan

Untuk itu perlu dilakukan perbaikan sebagai berikut: (1) Guru harus lebih memotivasi siswa supaya lebih aktif (2) Guru harus lebih memperhatikan peserta didik yang menghadapi kesulitan dalam menyelesaikan pekerjaannya. (3) Guru harus lebih jelas dalam mengarahkan apa-apa yang harus dikerjakan peserta didik.

\section{Hasil penelitian siklus 2}

\section{a. Perencanaan}

Siklus ke dua terdiri dari dua pertemuan, pada pertemuan pertama melakukan praktikum uji urin dan pertemuan ke dua membahas kandungan zat yang terdapat pada urin. Sebagai tindak lanjut dan perbaikan proses pembelajaran pada siklus pertama, maka peneliti dan observer merencanakan perbaikan proses pembelajaran agar dapat meningkatkan hasil belajar siswa baik aktifitasnya maupun hasil tesnya.

b. Pelaksanaan tindakan

Siklus ke dua dilaksanakan pada minggu ke 2 Agustus 2019. Pertemuan ke satu melaksanakan praktikum uji urin. Proses pembelajaran diawali dengan penjelasan dari Guru mengenai tujuan pembelajaran, apa yang harus dilakukan peserta didik dalam kelompok dalam melakukan praktikum uji urin. Selanjutnya tiap siswa mendapat LKS untuk dikerjakan sendiri setelah itu di diskusikan secara kelompok, sebagai bahan dalam menjawab pertanyaan yang terdapat dalam LKS dipergunankan media CD pembelajaran mengenai hubungan sistem ekskresi. Setelah siswa menerima LKS langsung memulai praktikum, bila ada yang belum jelas, kelompok meminta guru untuk mengulang penjelasan yang belum jelas. Setelah selesai tiap siswa mengerjakan sendiri lalu berpasangan kelompok berdiskusi untuk menjawab pertanyaan dalam LKS. Setelah selesai tiap kelompok mempresentasikan jawabanya dalam LKS di depan kelas.

Pada pertemuan ke dua yang membahas mengenai kandungan zat yang terdapat pada urin, metoda yang digunakan adalah sama yaitu diskusi secara kelompok. Kegiatan ini dimulai guru menyebutkan tujuan dari pembelajaran, kemudian menjelaskan apa yang harus dikerjakan dalam kelompok. Selanjutnya setiap kelompok diberikan bahan ajar yang harus dipelajari untuk dapat mengerjakan soal yang ada di LKS. Setelah selesai mengerjakan sendiri kemudian di diskusikan berpasangan, salah satu kelompok menulis salah satu jawaban yang ada di LKS pada papan tulis. Sedangkan LKS kelompok lain dikumpulkan untuk diperiksa lebih lanjut. Pertemuan ke dua diakhiri dengan tes.

c. Observasi

Berdasarkan pengamatan observer maupun peneliti peserta didik antusias dalam melakukan praktikum uji urin pada pertemuan pertama, demikian juga dalam mengerjakan LKS secara mandiri dan berkelompok. Sehingga ketika tiap kelompok membacakan hasil pekerjaanya, jawabah tiap kelompok hampir semuanya benar.

Demikian pada pertemuan ke dua yang membahas kandungan zat pada urin, siswa sudah terbiasa kerja kelompok dan belajar secara mandiri, sehingga tidak begitu kesulitan dalam menyelesaikan tugas dalam LKS. Untuk lebih jelasnya hasil aktivitas siswa dapat dilihat pada tabel berikut:

Tabel 5. Hasil Pengamatan Aktivitas Siswa Siklus Ke - Ii

\begin{tabular}{|c|c|c|c|c|}
\hline \multirow{2}{*}{ Kelompok } & Nama Siswa & $\begin{array}{c}\text { Skor } \\
\text { Perolehan }\end{array}$ & Skor Ideal & Persentase \\
\hline \multirow{2}{*}{1} & ANISA SRI RAHAYU & 15 & 16 & 93 \\
\cline { 2 - 2 } & BIAS FAJAR KHALIQ & 16 & \multicolumn{2}{|c|}{} \\
\hline
\end{tabular}


Vol. 1 No. 2 Desember 2021, e-ISSN : 2807-8667| p-ISSN : 2807-8837

\begin{tabular}{|c|c|c|c|c|}
\hline & CHELSI ANDESCO & & & \\
\hline & DANIA SARASWATI & & & \\
\hline & DIKI APRIAN & \multirow{4}{*}{12} & \multirow{4}{*}{16} & \multirow{4}{*}{93} \\
\hline & $\begin{array}{l}\text { DION ANUGRAH } \\
\text { PRATAMA }\end{array}$ & & & \\
\hline 2 & INDRI HIDAYANTI & & & \\
\hline & $\begin{array}{l}\text { INTAN YUNIA } \\
\text { CAHYANI }\end{array}$ & & & \\
\hline \multirow{4}{*}{3} & IRVAN TANJUNG & \multirow{4}{*}{14} & \multirow{4}{*}{16} & \multirow{4}{*}{87} \\
\hline & MELI WIDIANINGSIH & & & \\
\hline & MIMIN M & & & \\
\hline & $\begin{array}{l}\text { MUH LABIB } \\
\text { ZAMAKHSYARI }\end{array}$ & & & \\
\hline \multirow{4}{*}{4} & $\begin{array}{l}\text { MUHAMMAD ADNAN } \\
\text { ALFARIZI }\end{array}$ & \multirow{4}{*}{12} & \multirow{4}{*}{16} & \multirow{4}{*}{93} \\
\hline & MUHAMMAD RIZAL & & & \\
\hline & $\begin{array}{l}\text { MUHAMMAD } \\
\text { SIRAJUDIN }\end{array}$ & & & \\
\hline & $\begin{array}{l}\text { NADYA FEBRIYANTI } \\
\text { UTAMI }\end{array}$ & & & \\
\hline \multirow{4}{*}{5} & $\begin{array}{l}\text { NIK NIK HERNIKA } \\
\text { NIKEWATI }\end{array}$ & \multirow{4}{*}{12} & \multirow{4}{*}{16} & \multirow{4}{*}{75} \\
\hline & NINA RUSMAYANI & & & \\
\hline & NINDA NURLATIFAH & & & \\
\hline & $\begin{array}{l}\text { NOVITA } \\
\text { RAHMAWATI }\end{array}$ & & & \\
\hline \multirow{4}{*}{6} & NUKE MARLIANI & \multirow{4}{*}{12} & \multirow{4}{*}{16} & \multirow{4}{*}{75} \\
\hline & NURUL FAINI GORO & & & \\
\hline & PETI PAJRIATI & & & \\
\hline & PIPIT PITRIANA & & & \\
\hline \multirow{4}{*}{7} & $\begin{array}{l}\text { PUTRI AULIA } \\
\text { WITASYA }\end{array}$ & \multirow{4}{*}{13} & \multirow{4}{*}{16} & \multirow{4}{*}{81} \\
\hline & RINA SRI RAHAYU & & & \\
\hline & RISMA ASHOFI & & & \\
\hline & RIZKI APRIANI & & & \\
\hline \multirow{4}{*}{8} & ROSSYANA IRWANDI & \multirow{4}{*}{12} & \multirow{4}{*}{16} & \multirow{4}{*}{75} \\
\hline & RUDIANSYAH & & & \\
\hline & RUSLAN MAULANA & & & \\
\hline & $\begin{array}{l}\text { SATRIA RIZKI } \\
\text { ROHMAT }\end{array}$ & & & \\
\hline \multirow{4}{*}{9} & $\begin{array}{l}\text { SITI RAHAYU } \\
\text { NURLATIPAH }\end{array}$ & & & \\
\hline & $\begin{array}{l}\text { SITI SARAH } \\
\text { NURAENI }\end{array}$ & & & 75 \\
\hline & $\begin{array}{l}\text { SITI SARAH } \\
\text { NURDAYANTI }\end{array}$ & 12 & 16 & \\
\hline & $\begin{array}{l}\text { VINA YUNIA } \\
\text { MAULIDA }\end{array}$ & & & \\
\hline 10 & WINDA APRILIANI & 12 & 16 & 75 \\
\hline
\end{tabular}


Vol. 1 No. 2 Desember 2021, e-ISSN : 2807-8667| p-ISSN : 2807-8837

\begin{tabular}{|l|l|l|} 
ZULFAH MUSLIMAH & \multicolumn{1}{|c|}{} \\
\cline { 1 - 1 } NURDANIA & & \\
\cline { 1 - 2 } & SOFIE NUR FAUZIAH \\
ARIFIN & & \\
\hline
\end{tabular}

Kesimpulan mengenai aktivitas siswa pada siklus 2 dapat dilihat sebagai berikut:

Tabel 6. Data aktivitas siswa pada siklus 2

\begin{tabular}{|l|l|l|}
\hline aktivitas Siswa & Jumlah Siswa & Prosentase \\
\hline Tertinggi & 12 & $30 \%$ \\
\hline Sedang & 24 & $60 \%$ \\
\hline Terendah & 4 & $10 \%$ \\
\hline
\end{tabular}

Dari tabel data siswa pada siklus 2, aktivitas siswa tertinggi sebanyak $30 \%$, aktivitas siswa sedang sebanyak 60\% dan aktivitas siswa rendah sebanyak 10\%. Diagram aktivitas siswa pada siklus 2 dapat di lihat pada gambar di bawah ini

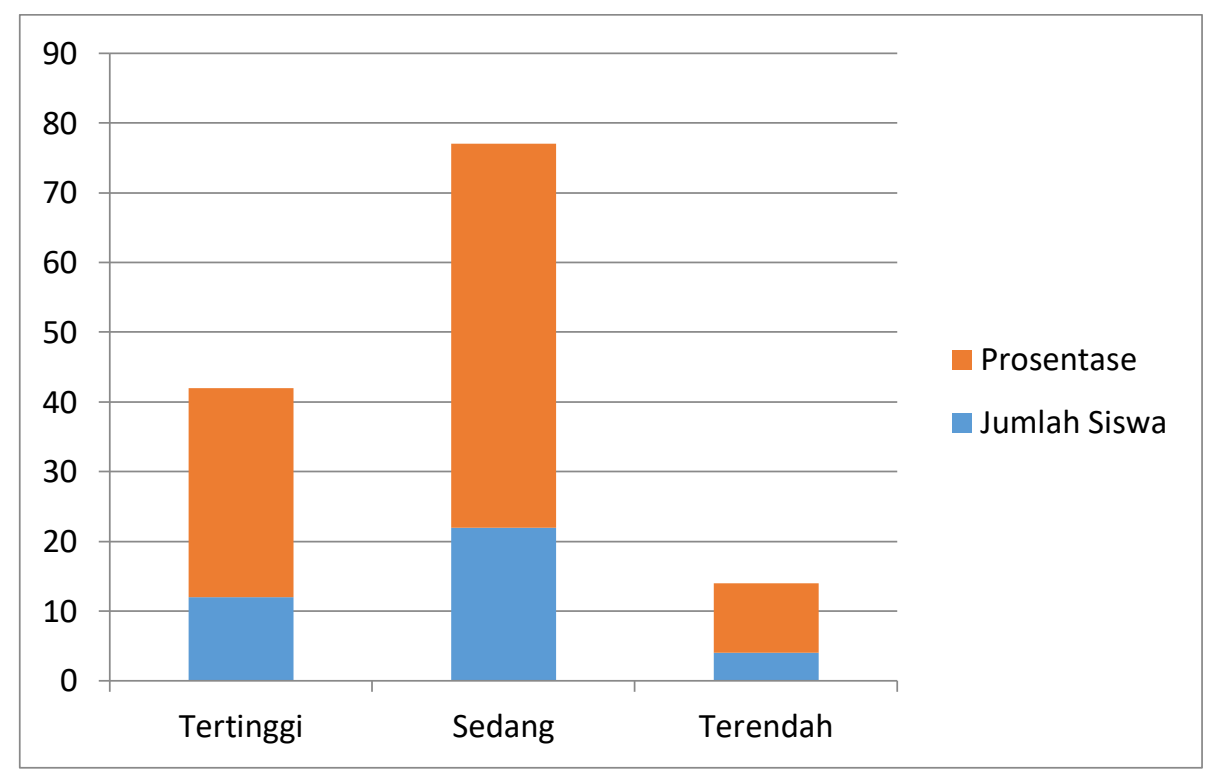

Gambar 3. Gambar aktivitas siswa pada siklus 2

Dari data aktivitas siswa siswa yang aktif hanya 2 kelompok yaitu sebanyak 8 orang dan yang lainnya masih kurang aktif, oleh karena itu peran guru harus lebih aktif dalam menerapkan model pembelajaran ini.

Tabel 7. Hasil Penilaian Siswa Pada Siklus Ii

\begin{tabular}{|c|c|c|c|c|c|c|c|c|}
\hline $\mathrm{N}$ & \multirow{2}{*}{ NAMA SISWA } & \multicolumn{5}{|c|}{ SKOR SOAL } & \multirow{2}{*}{$\begin{array}{c}\text { NILA } \\
\text { I }\end{array}$} & \multirow{2}{*}{$\begin{array}{c}\text { KETUNTASA } \\
\mathrm{N}\end{array}$} \\
\hline $\mathrm{O}$ & & 1 & 2 & 3 & 4 & 5 & & \\
\hline 1 & ANISA SRI RAHAYU & $\begin{array}{l}2 \\
0\end{array}$ & $\begin{array}{l}2 \\
0\end{array}$ & $\begin{array}{l}2 \\
0\end{array}$ & 0 & $\begin{array}{l}2 \\
0\end{array}$ & 80 & TUNTAS \\
\hline 2 & BIAS FAJAR KHALIQ & $\begin{array}{l}2 \\
0\end{array}$ & 0 & $\begin{array}{l}2 \\
0\end{array}$ & $\begin{array}{l}2 \\
0\end{array}$ & $\begin{array}{l}2 \\
0\end{array}$ & 80 & TUNTAS \\
\hline 3 & CHELSI ANDESCO & $\begin{array}{l}2 \\
0 \\
\end{array}$ & $\begin{array}{l}2 \\
0 \\
\end{array}$ & $\begin{array}{l}2 \\
0\end{array}$ & 0 & 0 & 60 & $\begin{array}{l}\text { TIDAK } \\
\text { TUNTAS }\end{array}$ \\
\hline
\end{tabular}


Vol. 1 No. 2 Desember 2021, e-ISSN : 2807-8667| p-ISSN : 2807-8837

\begin{tabular}{|c|c|c|c|c|c|c|c|c|}
\hline 4 & DANIA SARASWATI & $\begin{array}{l}2 \\
0 \\
\end{array}$ & $\begin{array}{l}2 \\
0 \\
\end{array}$ & $\begin{array}{l}2 \\
0 \\
\end{array}$ & $\begin{array}{l}2 \\
0 \\
\end{array}$ & $\begin{array}{l}2 \\
0 \\
\end{array}$ & 100 & TUNTAS \\
\hline 5 & DIKI APRIAN & $\begin{array}{l}2 \\
0\end{array}$ & $\begin{array}{l}2 \\
0\end{array}$ & 0 & $\begin{array}{l}2 \\
0 \\
\end{array}$ & $\begin{array}{l}2 \\
0\end{array}$ & 80 & TUNTAS \\
\hline 6 & DION ANUGRAH PRATAMA & $\begin{array}{l}2 \\
0\end{array}$ & $\begin{array}{l}2 \\
0\end{array}$ & $\begin{array}{l}2 \\
0 \\
\end{array}$ & $\begin{array}{l}2 \\
0 \\
\end{array}$ & $\begin{array}{l}2 \\
0\end{array}$ & 100 & TUNTAS \\
\hline 7 & INDRI HIDAYANTI & $\begin{array}{l}2 \\
0\end{array}$ & 0 & $\begin{array}{l}2 \\
0\end{array}$ & $\begin{array}{l}2 \\
0\end{array}$ & 0 & 60 & $\begin{array}{l}\text { TIDAK } \\
\text { TUNTAS }\end{array}$ \\
\hline 8 & INTAN YUNIA CAHYANI & $\begin{array}{l}2 \\
0\end{array}$ & $\begin{array}{l}2 \\
0\end{array}$ & 0 & $\begin{array}{l}2 \\
0\end{array}$ & $\begin{array}{l}2 \\
0\end{array}$ & 80 & TUNTAS \\
\hline 9 & IRVAN TANJUNG & $\begin{array}{l}2 \\
0\end{array}$ & $\begin{array}{l}2 \\
0\end{array}$ & $\begin{array}{l}2 \\
0 \\
\end{array}$ & $\begin{array}{l}2 \\
0 \\
\end{array}$ & $\begin{array}{l}2 \\
0\end{array}$ & 100 & TUNTAS \\
\hline 10 & MELI WIDIANINGSIH & $\begin{array}{l}2 \\
0\end{array}$ & $\begin{array}{l}2 \\
0\end{array}$ & $\begin{array}{l}2 \\
0\end{array}$ & $\begin{array}{l}2 \\
0\end{array}$ & $\begin{array}{l}2 \\
0\end{array}$ & 100 & TUNTAS \\
\hline 11 & MIMIN M & $\begin{array}{l}2 \\
0\end{array}$ & $\begin{array}{l}2 \\
0\end{array}$ & $\begin{array}{l}2 \\
0\end{array}$ & 0 & $\begin{array}{l}2 \\
0\end{array}$ & 80 & TUNTAS \\
\hline 12 & MUH LABIB ZAMAKHSYARI & $\begin{array}{l}2 \\
0 \\
\end{array}$ & $\begin{array}{l}2 \\
0 \\
\end{array}$ & $\begin{array}{l}2 \\
0 \\
\end{array}$ & $\begin{array}{l}2 \\
0 \\
\end{array}$ & $\begin{array}{l}2 \\
0 \\
\end{array}$ & 100 & TUNTAS \\
\hline 13 & $\begin{array}{l}\text { MUHAMMAD ADNAN } \\
\text { ALFARIZI }\end{array}$ & $\begin{array}{l}2 \\
0\end{array}$ & $\begin{array}{l}2 \\
0\end{array}$ & 0 & $\begin{array}{l}2 \\
0\end{array}$ & $\begin{array}{l}2 \\
0\end{array}$ & 80 & TUNTAS \\
\hline 14 & MUHAMMAD RIZAL & $\begin{array}{l}2 \\
0\end{array}$ & $\begin{array}{l}2 \\
0\end{array}$ & $\begin{array}{l}2 \\
0 \\
\end{array}$ & $\begin{array}{l}2 \\
0\end{array}$ & $\begin{array}{l}2 \\
0\end{array}$ & 100 & TUNTAS \\
\hline 15 & MUHAMMAD SIRAJUDIN & $\begin{array}{l}2 \\
0\end{array}$ & 0 & $\begin{array}{l}2 \\
0\end{array}$ & 0 & $\begin{array}{l}2 \\
0\end{array}$ & 60 & $\begin{array}{l}\text { TIDAK } \\
\text { TUNTAS }\end{array}$ \\
\hline 16 & NADYA FEBRIYANTI UTAMI & $\begin{array}{l}2 \\
0\end{array}$ & $\begin{array}{l}2 \\
0\end{array}$ & $\begin{array}{l}2 \\
0\end{array}$ & 0 & $\begin{array}{l}2 \\
0\end{array}$ & 80 & TUNTAS \\
\hline 17 & NIK NIK HERNIKA NIKEWATI & $\begin{array}{l}2 \\
0\end{array}$ & $\begin{array}{l}2 \\
0\end{array}$ & $\begin{array}{l}2 \\
0 \\
\end{array}$ & $\begin{array}{l}2 \\
0\end{array}$ & $\begin{array}{l}2 \\
0\end{array}$ & 100 & TUNTAS \\
\hline 18 & NINA RUSMAYANI & $\begin{array}{l}2 \\
0\end{array}$ & $\begin{array}{l}2 \\
0\end{array}$ & $\begin{array}{l}2 \\
0\end{array}$ & $\begin{array}{l}2 \\
0\end{array}$ & 0 & 80 & TUNTAS \\
\hline 19 & NINDA NURLATIFAH & $\begin{array}{l}2 \\
0\end{array}$ & $\begin{array}{l}2 \\
0\end{array}$ & $\begin{array}{l}2 \\
0\end{array}$ & $\begin{array}{l}2 \\
0\end{array}$ & $\begin{array}{l}2 \\
0\end{array}$ & 100 & TUNTAS \\
\hline 20 & NOVITA RAHMAWATI & $\begin{array}{l}2 \\
0\end{array}$ & $\begin{array}{l}2 \\
0\end{array}$ & $\begin{array}{l}2 \\
0\end{array}$ & 0 & $\begin{array}{l}2 \\
0\end{array}$ & 80 & TUNTAS \\
\hline 21 & NUKE MARLIANI & $\begin{array}{l}2 \\
0\end{array}$ & $\begin{array}{l}2 \\
0\end{array}$ & 0 & $\begin{array}{l}2 \\
0\end{array}$ & $\begin{array}{l}2 \\
0\end{array}$ & 80 & TUNTAS \\
\hline 22 & NURUL FAINI GORO & $\begin{array}{l}2 \\
0\end{array}$ & $\begin{array}{l}2 \\
0\end{array}$ & $\begin{array}{l}2 \\
0 \\
\end{array}$ & $\begin{array}{l}2 \\
0\end{array}$ & $\begin{array}{l}2 \\
0\end{array}$ & 100 & TUNTAS \\
\hline 23 & PETI PAJRIATI & $\begin{array}{l}2 \\
0\end{array}$ & 0 & $\begin{array}{l}2 \\
0 \\
\end{array}$ & 0 & $\begin{array}{l}2 \\
0\end{array}$ & 60 & $\begin{array}{l}\text { TIDAK } \\
\text { TUNTAS }\end{array}$ \\
\hline 24 & PIPIT PITRIANA & $\begin{array}{l}2 \\
0 \\
\end{array}$ & $\begin{array}{l}2 \\
0 \\
\end{array}$ & $\begin{array}{l}2 \\
0 \\
\end{array}$ & $\begin{array}{l}2 \\
0 \\
\end{array}$ & $\begin{array}{l}2 \\
0 \\
\end{array}$ & 100 & TUNTAS \\
\hline 25 & PUTRI AULIA WITASYA & $\begin{array}{l}2 \\
0 \\
\end{array}$ & $\begin{array}{l}2 \\
0 \\
\end{array}$ & $\begin{array}{l}2 \\
0 \\
\end{array}$ & $\begin{array}{l}2 \\
0 \\
\end{array}$ & $\begin{array}{l}2 \\
0 \\
\end{array}$ & 100 & TUNTAS \\
\hline 26 & RINA SRI RAHAYU & $\begin{array}{l}2 \\
0 \\
\end{array}$ & $\begin{array}{l}2 \\
0 \\
\end{array}$ & $\begin{array}{l}2 \\
0 \\
\end{array}$ & $\begin{array}{l}2 \\
0 \\
\end{array}$ & $\begin{array}{l}2 \\
0 \\
\end{array}$ & 100 & TUNTAS \\
\hline 27 & RISMA ASHOFI & 0 & $\begin{array}{l}2 \\
0 \\
\end{array}$ & $\begin{array}{l}2 \\
0 \\
\end{array}$ & $\begin{array}{l}2 \\
0 \\
\end{array}$ & 0 & 60 & $\begin{array}{l}\text { TIDAK } \\
\text { TUNTAS }\end{array}$ \\
\hline 28 & RIZKI APRIANI & $\begin{array}{l}2 \\
0\end{array}$ & $\begin{array}{l}2 \\
0\end{array}$ & $\begin{array}{l}2 \\
0 \\
\end{array}$ & $\begin{array}{l}2 \\
0\end{array}$ & $\begin{array}{l}2 \\
0\end{array}$ & 100 & TUNTAS \\
\hline
\end{tabular}


Vol. 1 No. 2 Desember 2021, e-ISSN : 2807-8667| p-ISSN : 2807-8837

\begin{tabular}{|c|c|c|c|c|c|c|c|c|}
\hline 29 & ROSSYANA IRWANDI & $\begin{array}{l}2 \\
0\end{array}$ & $\begin{array}{l}2 \\
0\end{array}$ & $\begin{array}{l}2 \\
0\end{array}$ & $\begin{array}{l}2 \\
0\end{array}$ & $\begin{array}{l}2 \\
0\end{array}$ & 100 & TUNTAS \\
\hline 30 & RUDIANSYAH & $\begin{array}{l}2 \\
0\end{array}$ & $\begin{array}{l}2 \\
0\end{array}$ & 0 & $\begin{array}{l}2 \\
0\end{array}$ & $\begin{array}{l}2 \\
0\end{array}$ & 80 & TUNTAS \\
\hline 31 & RUSLAN MAULANA & $\begin{array}{l}2 \\
0\end{array}$ & $\begin{array}{l}2 \\
0\end{array}$ & $\begin{array}{l}2 \\
0\end{array}$ & 0 & $\begin{array}{l}2 \\
0\end{array}$ & 80 & TUNTAS \\
\hline 32 & SATRIA RIZKI ROHMAT & $\begin{array}{l}2 \\
0\end{array}$ & $\begin{array}{l}2 \\
0\end{array}$ & 0 & $\begin{array}{l}2 \\
0\end{array}$ & $\begin{array}{l}2 \\
0\end{array}$ & 80 & TUNTAS \\
\hline 33 & SITI RAHAYU NURLATIPAH & $\begin{array}{l}2 \\
0\end{array}$ & 0 & $\begin{array}{l}2 \\
0\end{array}$ & $\begin{array}{l}2 \\
0\end{array}$ & $\begin{array}{l}2 \\
0\end{array}$ & 80 & TUNTAS \\
\hline 34 & SITI SARAH NURAENI & $\begin{array}{l}2 \\
0\end{array}$ & $\begin{array}{l}2 \\
0\end{array}$ & $\begin{array}{l}2 \\
0\end{array}$ & $\begin{array}{l}2 \\
0\end{array}$ & $\begin{array}{l}2 \\
0\end{array}$ & 100 & TUNTAS \\
\hline 35 & SITI SARAH NURDAYANTI & $\begin{array}{l}2 \\
0\end{array}$ & $\begin{array}{l}2 \\
0\end{array}$ & $\begin{array}{l}2 \\
0\end{array}$ & $\begin{array}{l}2 \\
0\end{array}$ & $\begin{array}{l}2 \\
0\end{array}$ & 100 & TUNTAS \\
\hline 36 & VINA YUNIA MAULIDA & $\begin{array}{l}2 \\
0\end{array}$ & 0 & $\begin{array}{l}2 \\
0\end{array}$ & $\begin{array}{l}2 \\
0\end{array}$ & $\begin{array}{l}2 \\
0\end{array}$ & 80 & TUNTAS \\
\hline 37 & WINDA APRILIANI & $\begin{array}{l}2 \\
0 \\
\end{array}$ & $\begin{array}{l}2 \\
0\end{array}$ & $\begin{array}{l}2 \\
0\end{array}$ & $\begin{array}{l}2 \\
0\end{array}$ & $\begin{array}{l}2 \\
0\end{array}$ & 100 & TUNTAS \\
\hline 38 & ZULFAH MUSLIMAH & $\begin{array}{l}2 \\
0\end{array}$ & 0 & $\begin{array}{l}2 \\
0\end{array}$ & $\begin{array}{l}2 \\
0\end{array}$ & $\begin{array}{l}2 \\
0\end{array}$ & 80 & TUNTAS \\
\hline 39 & NURDANIA & $\begin{array}{l}2 \\
0 \\
\end{array}$ & $\begin{array}{l}2 \\
0\end{array}$ & $\begin{array}{l}2 \\
0\end{array}$ & $\begin{array}{l}2 \\
0\end{array}$ & $\begin{array}{l}2 \\
0\end{array}$ & 100 & TUNTAS \\
\hline 40 & SOFIE NUR FAUZIAH ARIFIN & $\begin{array}{l}2 \\
0\end{array}$ & $\begin{array}{l}2 \\
0\end{array}$ & $\begin{array}{l}2 \\
0\end{array}$ & $\begin{array}{l}2 \\
0\end{array}$ & $\begin{array}{l}2 \\
0\end{array}$ & 100 & TUNTAS \\
\hline
\end{tabular}

Untuk mengetahui besaran nilai hasil tes siswa, maka pada akhir siklus 2 dilakukan tes dan dapat dilihat sebagai berikut:

Tabel 8. Daftar nilai hasil belajar siswa pada siklus 2

\begin{tabular}{|l|l|l|l|}
\hline Rata-rata & Nilai tertinggi & Nilai terendah & Ketuntasan (\%) \\
\hline 87 & 100 & 60 & 87,5 \\
\hline
\end{tabular}

Nilai hasil belajar siswa pada siklus 2 dapat dilihat pada gambar di bawah ini

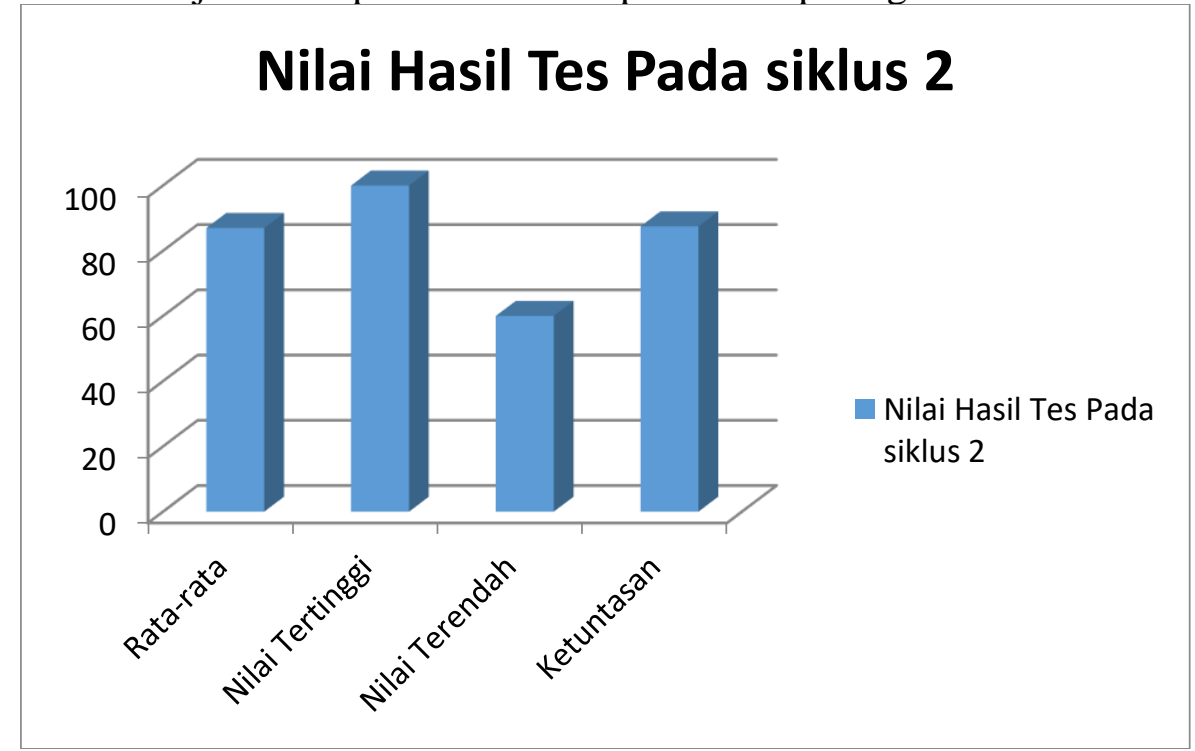

Gambar 4. Gambar nilai hasil belajar siswa pada siklus 2 
Berdasarkan hasil ulangan harian, nilai rata-rata kelas 87, siswa sudah mencapai KKM sebanyak 35 orang sedangkan 5 yang memperoleh nilai di bawah KKM. Dengan demikian persentase peserta didik yang nilai tes nya mencapai KKM hanya $87,50 \%$, sisanya belum mencapai KKM. Pada siklus ke dua terdapat peningkatan yang drastis dari siklus ke satu.

d. Refleksi

Pada pelaksanaan siklus ke dua guru lebih aktif dalam melakukan bimbingan terhadap kelompok yang mendapat kesulitan dalam mengerjakan tugas. Selain itu peserta didik mulai terbiasa bekerja sama dengan kelompoknya. Sehingga terjadi beberapa perubahan dalam proses pembelajaran, diantaranya: ada peningkatan aktifitas dan kreatifitas peserta didik juga nilai hasil tes keterampilan proses sain nya. Selain itu adanya antusias siswa ketika melihat melakukan keterampilan proses sains uji urin pada materi sistem ekskresi.

\section{Pembahasan Hasil Penelitian}

Penelitian Tindakan Kelas ini terdiri dari 2 siklus dan dilaksanakan dalan 4 kali pertemuan (8x45 menit). Temuan dalam Penelitian Tindakan Kelas ini menunjukan terjadinya peningkatan hasil belajar dalam keterampilan proses sains siswa yang sangat drastis pada materi sistem ekskresi di kelas XI IPA3 dengan menggunakan model pembelajaran kooperatipe STAD pada hasil belajar siswa. berikut:

Kesimpulan mengenai aktivitas siswa pada siklus 1 dan siklus 2 dapat dilihat sebagai

Tabel 9. Data aktivitas siswa pada siklus 1 dan siklus 2

\begin{tabular}{|l|l|l|l|l|}
\hline \multirow{2}{*}{\begin{tabular}{l} 
Sktivitas \\
\cline { 2 - 5 }
\end{tabular}} & $\begin{array}{l}\text { Jumlah } \\
\text { Siswa }\end{array}$ & Prosentase & $\begin{array}{l}\text { Jumlah } \\
\text { Siswa }\end{array}$ & Prosentase \\
\hline Tertinggi & 8 & $20 \%$ & 12 & $30 \%$ \\
\hline Sedang & 28 & $70 \%$ & 24 & $60 \%$ \\
\hline Terendah & 4 & $10 \%$ & 4 & $10 \%$ \\
\hline Jumlah & 40 & 100 & 40 & 100 \\
\hline
\end{tabular}

Berdasarkan tabel data aktivitas siswa siklus 1 dan siklus 2, persentase aktivitas siswa tertinggi pada siklus 2 dibandingkan pada siklus 1 .

Diagram aktivitas siswa pada siklus 1 dan siklus 2 dapat dilihat dalam gambar di bawah ini

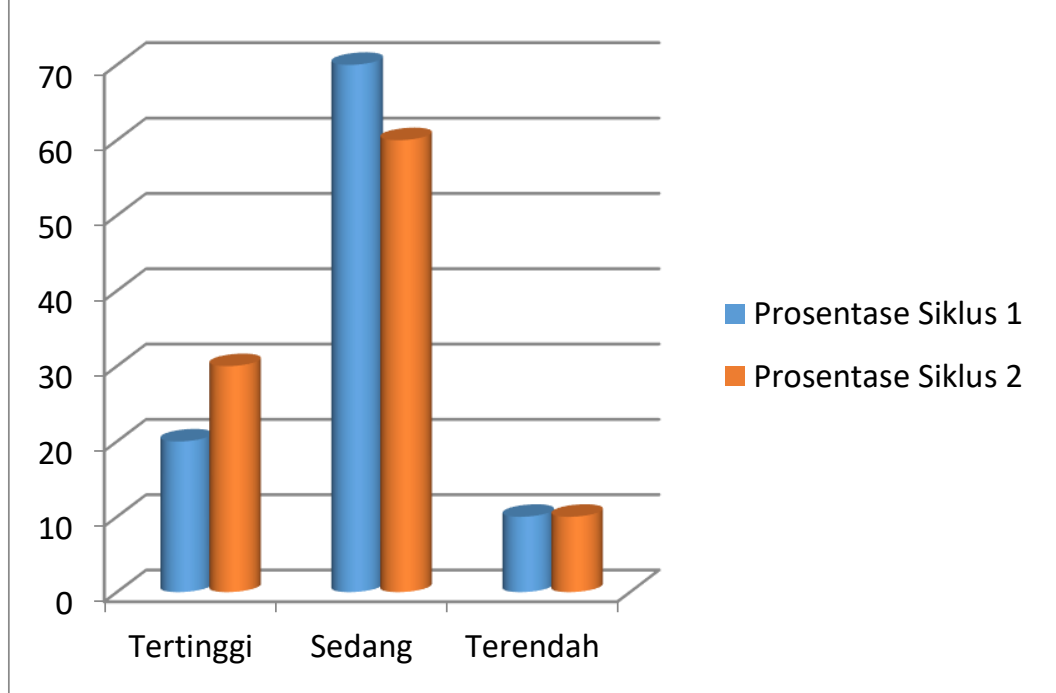

Gambar 5. Diagram aktivitas siswa pada siklus 1 dan siklus 2 
Vol. 1 No. 2 Desember 2021, e-ISSN : 2807-8667| p-ISSN : 2807-8837

Prosentase aktifitas siswa tertinggi pada siklus 1 sebesar $20 \%$ sedangkan pada siklus 2 ada peningkatan sebesar $30 \%$, sebagian besar masih harus ditingkatkan lagi aktivitas nya.

Tabel 10. Daftar nilai hasil belajar siswa pada siklus 1 dan siklus 2

\begin{tabular}{|l|l|l|l|l|}
\hline Kegiatan & Rata-rata & Nilai tertinggi & Nilai terendah & Ketuntasan (\%) \\
\hline Siklus 1 & 72,75 & 80 & 50 & 77,5 \\
\hline Siklus 2 & 87 & 100 & 60 & 87,5 \\
\hline
\end{tabular}

Berdasarkan daftar nilai hasil belajar siswa pada siklus 1 dan siklus 2, ketuntasan siswa pada siklus 1 sebesar 77,7\% dan siklus 2 sebesar 87,5\%. Pesentase hasil belajar siklus 2 lebih tinggi dari siklus 2 .

Diagram nilai hasil belajar siswa pada siklus 1 dan siklus 2 dapat dilihat dalam gambar di bawah ini

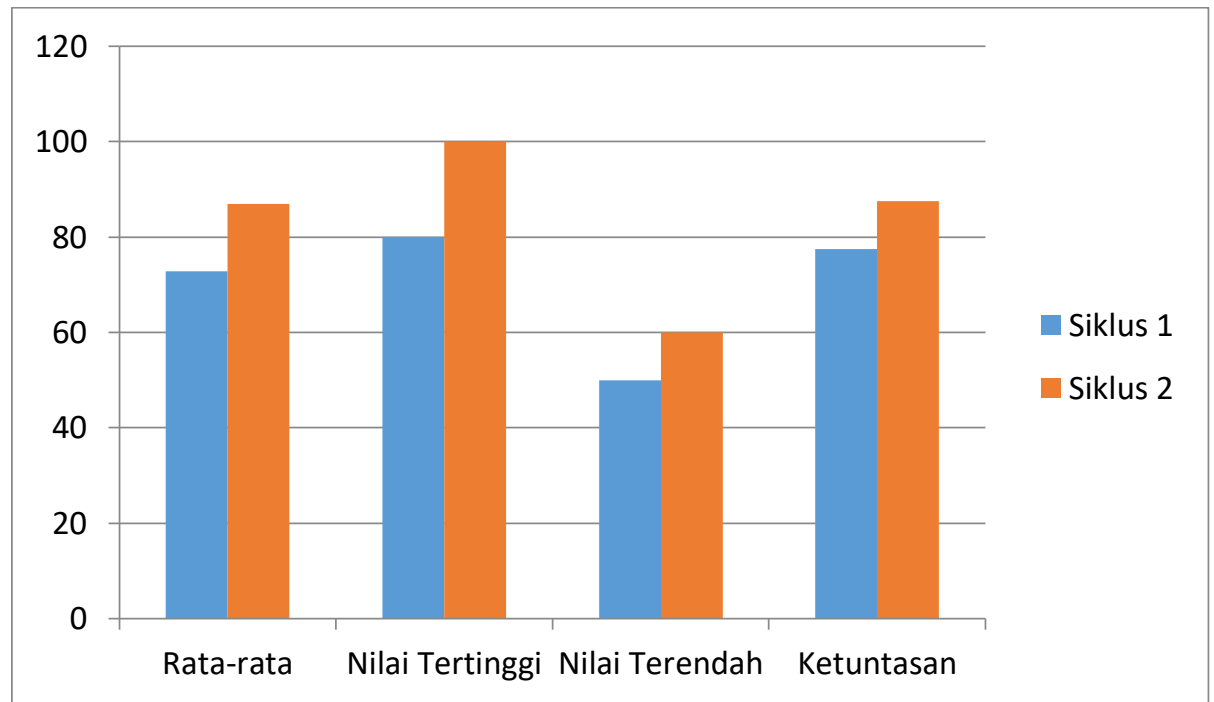

Gambar 6. Gambar nilai hasil belajar siswa pada siklus 1 dan siklus 2

Nilai hasil tes dari siklus pertama ke siklus kedua terdapat peningkatan. Pada siklus pertama diperoleh hasil tes tertinggi 72,75 sedangkan pada siklus kedua dipeoleh nilai 87 . Nilai tes mengalami kenaikan dari siklus pertama ke siklus ke dua, baik rata-rata nilai maupun jumlah peserta didik yang mencapai KKM. Pada siklus pertama rata-rata 77,5\% peserta didik yang nilai hasil tesnya sudah mencapai KKM, berarti 22,5\% belum mencapai KKM. Pada siklus kedua peserta didik yang nilai hasil tes sudah mencapai KKM adalah 87,5\%, dan 12,5\% belum mencapai KKM. Prayitno, B.A. (2010) menyatakan strategi inkuiri terbimbing dipadu kooperatif STAD dapat berpengaruh terhadap kemampuan berfikir tingkat tinggi, metakognitif, dan keterampilan proses sains.

\section{KESIMPULAN}

Berdasarkan hasil penelitian tindakan kelas yang dilakukan di SMAN 1 Cisaat Kabupaten Sukabumi, pada kelas XI IPA3 Semester genap tahun 2019 maka diperoleh kesimpulan bahwa Penggunaan Model Pembelajaran Kooperatif STAD (Student Teams Achievement Division) dapat meningkatkan aktivitas belajar peserta didik pada materi Sistem Ekskresi. Penggunaan model pembelajaran Kooperatif STAD (Student Teams Achievement Division) dapat meningkatkan nilai tes peserta didik, pada materi sistem ekskresi, dapat meningkatkan jumlah peserta didik yang mencapai KKM pada materi sistem ekskresi. Penggunaan model pembelajaran yang bervariasi dapat membuat siswa tidak bosan untuk belajar. Prosentase aktifitas siswa tertinggi pada siklus 1 sebesar $20 \%$ sedangkan pada siklus 2 ada peningkatan sebesar $30 \%$, sebagian besar masih harus ditingkatkan lagi aktivitas nya. Nilai hasil tes dari siklus pertama ke siklus kedua terdapat peningkatan. Pada siklus pertama diperoleh hasil tes tertinggi 72,75 sedangkan pada siklus kedua dipeoleh nilai 87 . Nilai tes 
mengalami kenaikan dari siklus pertama ke siklus ke dua, baik rata-rata nilai maupun jumlah peserta didik yang mencapai KKM. Pada siklus pertama rata-rata 77,5\% peserta didik yang nilai hasil tesnya sudah mencapai KKM, berarti $22,5 \%$ belum mencapai KKM. Pada siklus kedua peserta didik yang nilai hasil tes sudah mencapai KKM adalah $87,5 \%$, dan $12,5 \%$ belum mencapai KKM.

\section{DAFTAR PUSTAKA}

Arends, Richard I. (2008). Learning to teach. Yogyakarta: Pustaka Pelajar.

Arikunto, Suharsimi. (2006). Prosedur penelitian suatu pendekatan praktik. Jakarta PT Rineka Cipta

Dimyati dan Mudjiono. (2009). Belajar dan pembelajaran. Jakarta: Rineka Cipta.

Dahar, R.W. (1996). Teori-teori belajar. Jakarta: Erlangga.

Eggen, Paul \& Don Kauchak. (2012). Strtegi dan model pembelajaran. Jakarta : Indeks.

Firman, H. (2000). Penilaian hasil belajar dalam pengajaran kimia. Bandung: Jurusan Pendidikan Kimia FPMIPA UPI.

Hakim, Lukmanul. (2009) Perencanaan pembelajaran. Bandung : CV. Wacana Prima.

Isjoni. (2009) Cooperative learning, mengembangkan kemampuan belajar Kelompok. Bandung: Alfabeta.

Lie, Anita. (2008). Cooperative learning. Jakarta: Gramedia Widyasarana Indonesia.

Mutmainah, Iis Siti. (2009). Penerapan model pembelajaran kooperatif Tipe Think Pair Share (TPS) untuk meningkatkan hasil belajar kognitif siswa pada materi pokok virus. Skripsi. Tidak diterbitkan.

Prayitno, B.A. (2010). Potensi Pembelajaran Kooperatif dalam Memberdayakan Prestasi Belajar Siswa Under Achievment (Upaya mensejajarkan Prestasi Belajar Siswa Akademik Bawah dengan Siswa Akademik Atas). In Prosiding Seminar Biologi (Vol.7.No.1).

Rusman. (2012). Model-model pembelajaran. Jakarta : PT. Raja Grafindo Persada.

Rustaman, N.Y., dkk. (2003). Strategi belajar mengajar biologi. Bandung: Jurusan Pendidikan Biologi FPMIPA UPI.

Slavin Robert E. (2010). Cooperative learning. London : Allymand Bacon.

Sudjana, Nana. (2009). Dasar-dasar proses belajar mengajar. Bandung: Sinar Baru Algesindo.

Sukmara, Dian. (2007). Implementasi life skill Kurikulum Tingkat Satuan Pendidikan (KTSP): melalui model manajemen potensial qodrati. Bandung: CV Mughni Sejahtera.

Sugiyono. (2012). Metode penelitian pendidikan pendekatan kuantitatif, kualitatif. Bandung : Alfabeta.

Sugiyono. (2013). Metode penelitian kombinasi. Bandung : Alfabeta. . (2012). Metode penelitian pendidikan pendekatan kuantitatif, kualitatif. Bandung : Alfabeta.

Syah, Muhibbin. (2008). Psikologi pendidikan dengan pendekatan baru. Bandung: PT Remaja Rosdakarya.

Trianto. (2009). Mendesain model pembelajaran inovatif progresif: konsep, landasan, dan implementasi pada Kurikulum Tingkat Satuan Pendidikan (KTSP). Jakarta: Kencana Prenada Media Group.

. (2010). Model pembelajaran terpadu, Surabaya: PT. Bumi Aksara.

W.S. Winkel. (2012). Psikologi pengajaran, Yogyakarta : Media Abadi.

Zulfiani, dkk. (2009). Strategi pembelajaran sains. Lembaga Penelitian UIN Jakarta. 